\title{
PROBLEMATIKA ONLINE LEARNING; HAMBATAN PEMBELAJARAN BAHASA INGGRIS SISWA
}

\author{
Oleh \\ Ulfan Mulyawan \\ Sekolah Tinggi Pariwisata Mataram \\ Email: ulfanmbojonis@gmail.com
}

\begin{abstract}
Abstrak
Kebijakan terkait online learning yang kemudian serempak digunakan sebagai sistem pembelajaran bukannya muncul tanpa permasalahan. Imbasnya, bagi negara yang kurang siap dengan sistem ini, sudah tentu menghadapi banyak masalah terlebih bagi Tenaga pengajar dan peserta didik. Penelitian ini, mencoba mendalami permasalahan yang berpotensi menghambat pemahaman siswa selama belajar secara online, dimana, hal ini berarti bahwa peneliti hanya akan focus pada hambatan dalam proses pembelajaran baik internal siswa maupun eksternal dari guru dan orang tua bukan hal-hal teknis seperti kendala jaringan, tidak ada kuota dan hal terkait lainnya. Subject dalam penelitian ini adalah 15 siswa tingkat SMP di Penan, Pejarakan, Ampenan. Penelitian kualitatif dengan pendekatan deskriptif ini, didalam prosesnya menggunakan metode Observasi dan Wawancara sebagai cara utama untuk mendapatkan data dimana hasil penelitian ini mengklasifikasi permasalahan utama yang muncul menjadi 3 bagian yakni; 1) Adanya keterlambatan dari subject dalam mengikuti kegiatan kelas daring, 2) Adanya kecenderungan tidak serius mengikuti kegiatan belajar dengan melakukan kegiatan lain seperti bermain game, menonton TV dan kegiatan lain serta 3) kurang maksimalnya waktu dan kemampuan pendamping selama proses belajar baik karna tidak memiliki pemahaman yang cukup terkait materi maupun adanya kegiatan lain atau pekerjaan yang harus dijalani.
\end{abstract}

\section{Keywords: Online Learning \& Hambatan Pembelajaran Bahasa Inggris}

\section{PENDAHULUAN}

Sistem pembelajaran tatap muka "face to face learning" di sekolah merupakan sistem yang selama ini paling dominan dilaksanakan disebagian besar Negara dunia sebelum akhirnya harus mengalami perubahan drastis sejak mewabahnya pandemic COVID-19 di awal tahun 2019. Guna menghindari dan mengendalikan penyebarannya , langkah cepatpun diambil banyak negara termasuk di dalam bidang pendidikan dengan mengeluarkan regulasi khusus terkait pelaksanaan kegiatan belajar mengajar. Reaksi serupa kemudian juga diambil oleh pemerintah Indonesia melalui menteri pendidikan dengan diterbitkannya Surat Edaran No. 4 tentang Pelaksanaan Kebijakan Pendidikan dalam Masa Darurat Penyebaran Corona Virus Disease (Covid-19) dimana salah satu poinnya adalah anjuran belajar dari rumah. Praktis kemudian system pelaksanaan belajar secara tatap muka atau "face to face learning"-pun tergantikan secara masif oleh pembelajaran online dan hal tersebut harus dijalankan diseluruh jenjang pendidikan baik sekolah pada level dasar, Menengah dan atas serta universitas. Dampaknya, ada setidaknya 28 juta lebih siswa di tingkat SD-SMA yang harus melaksanakan pembelajaran dari rumah (Arwen, 2020). Tentu keputusan ini menjadi sangat relevan jika dikaitkan dengan usaha untuk bertahan dan menjaga keselamatan ditengah kondisi mewabahnya virus. Namun, jika keputusan tersebut dikaitkan dengan pelaksanaan pendidikan maka hal ini kemudian menimbulkan banyak pertanyaan terutama dalam hal kesiapan yang harus dilaksanakan banyak pihak terlebih bagi mereka yang ada di garda terdepan sebagai pelaksana dan peserta dalam dunia pendidikan yakni tenaga pengajar dan peserta didik. 
Kesiapan ini tentu mencakup banyak hal seperti sarana dan prasarana pendukung kegiatan dalam bentuk media seperti HP atau Laptop, pengetahuan pengoperasian alat tersebut, pengetahuan penggunaan aplikasi belajar dan hal-hal terkait lainnya. Jika dilihat dari aspek sarana dan prasarana misalnya, kesiapan fisik dari teknologi sebagai media kelas daring tersebut setidaknya harus terpenuhi dengan syarat minimal semua pengajar dan peserta didik memiliki smarthphone atau laptop yang dapat terkoneksi jaringan internet secara merata karena secara logis tidak akan bisa pembelajaran berlangsung jika hanya Guru yang memiliki sarana tersebut atau akan jauh lebih miris jika sebaliknya. Namun, sudah tentu memiliki sarana seperti HP dan Laptop saja tidak cukup dalam mengikuti kelas daring karna hal lain yang dibutuhkan dari kelas online adalah wajib memiliki data agar dapat mengakses jaringan.

Tidak henti sampai disitu, hal penting lain dari persiapan pada perubahan system pembelajaran ini adalah tingkat kemampauan mengajar oleh guru dengan segala bahan ajar yang kemudian harus ditransfer kedalam kelas virtual yang jika itu adalah materi bacaan maka setidaknya harus disampaikan dalam bentuk soft file. Bagi guru yang terbiasa dengan penggunaan media dalam proses mengajar dan dengan fasilitas memadai, tentu hal ini bukan hambatan besar. Namun, tentu saja keahlian tersebut tidak bisa disama ratakan dengan guruguru yang ada di daerah-daerah seluruh Indonesia.

Hal yang kemudian menjadi menarik adalah, jika para guru merasa tidak maksimal dan bahkan terkendala dalam menjalankan pengajaran secara online, maka pendalaman terkait masalah ini juga perlu diungkap dari perspektif peserta didik dan tentu saja pada orang tua yang ada dikawasan Penan, Pejarakan.

\section{LANDASAN TEORI}

\section{Belajar Online (Online Learning)}

Online learning (pembelajaran online) yang juga memiliki beberapa istilah seperti networked learning, computer assisted learning atau virtual learning sejatinya telah berkembang sejak tahun 1970-an (Setiawardhani, 2003) dimana awal kemunculannya, semua istilah tersebut berada dibawah payung e-learning (Litlejohn \& Pegler, 2007). Konsep awal e-learning yang secara harfiah merupakan singkatan dari "Electronic Learning" dan memiliki arti Pembelajaran Elektronik kini telah berganti dimana hururf "e" yang seharusnya berarti Electronic kini menjadi lebih familiar dengan makna Internet di masyarakat umum (Hendrastomo, 2008), dimana, hal itu menggiring khalayak umum pada sebuah asumsi bahwa imbuhan "e" diawal penamaan sistem atau aplikasi penggunaannya mengharuskan adanya jaringan internet atau berbasis jaringan internet.

e-Learning atau Vitual Learning yang biasanya mengacu pada proses pembelajaran melalui kelas maya dengan perangkat utama berupa jaringan komputer (Munawaroh, 2018) merupakan konsep belajar yang memiliki fleksibilitas tinggi karna dimanapun anda berada, kegiatan belajar dapat diakses (Hendrastomo, 2008), sehingga penggunaan eLearning ini dapat berguna untuk memudahkan akses pengetahuan serta peningkatan keterampilan siswa (Yustanti \& Novita, 2019). Jadi, sejatinya, online learning dapat dengan sederhana ditujukan ke sebuah konsep kegiatan belajar dan mengajar yang tergantung pada adanya media dan jaringan dalam melaksanakannya guna mempermudah akses bagi siswa.

e-Learning menurut Chitra \& Raj, (2018) memiliki 3 jenis utama yakni; 1) Text Driven, dimana materi pembelajaran masih sederhana berupa teks, gambar, audio dan soal-soal. 2) Interactive, yang sebenarnya tidak jauh berbeda dengan type sebelumnya, merupakann tipe yang di dalam aplikasinya lebih menekankan hal-hal interaktif seperti diagram, grafis atau table guna meningkatkan semangat belajar dan 3) Simulation, merupakan pembelajaran online yang jauh lebih interaktif karna melibatkan simulasi bergambar seperti adanya unsur 3D didalamnya. 
Belajar online sudah tentu memiliki perbedaan signifikan dengan pembelajaran tatap muka baik itu dari segi penyampaian oleh guru, suasana belajar, jarak dan bahkan dari segi motifasi dan daya serap peserta didiknya. Dalam melaksanakan proses belajar online Dabbagh (2007) menyebutkan bahwa ada beberapa hal yang harus dilakukan oleh seorang peserta belajar dalam kegiatan belajar online yakni:

1. Mampu menggunakan teknologi pembelajaran online khususnya teknologi komunikasi dan kolaboratif.

2. Memiliki concept akademik mandiri yang kuat serta kemampuan komunikasi serta interaksi yang baik

3. Memiliki pemahaman dasar dan ketertarikan terhadap belajar kelompok dan membangun kompetensi terhadap skill terkait.

4. Memiliki kemampuan belajar mandiri melalui pengaturan manajemen waktu dan strategi pembelajaran kognitif.

Hal-hal ini tentu saja berbeda jika dibandingkan dengan kelas tatap muka yang tidak banyak mengharuskan peserta didik untuk terampil menggunakan teknologi virtual learning.

Senada dengan ciri di atas, Hardianto (2012:5\&6) dalam cakupan yang lebih luas menyebutkan bahwa ada sejumlah hal yang harus dimiliki oleh guru dan siswa didalam pembelajaran online. Dari aspek pendidik, setidaknya hal-hal berupa penguasaan internet, penguasaan ilmu pengetahuan, kreatifitas dan inovasi, kemampuan memotifasi, mumpuni dalam konsep pembelajaran online, pengelolaan system, pemilihan bahan ajar yang tepat serta penguasaan kontroling kelas harus ada dan dapat diaplikasikan dengan baik. Dari aspek siswa hal-hal yang harus tertanam di dalam dirinya dalam menjalankan kelas online adalah adanya kemandirian, kemampuan mengoperasikan teknologi, keteguhan, tanggung jawab belajar, motifasi tinggi, interkatif serta kreatif dan Inovatif. Apabila diamati lebih dalam, bahkan tingkat kemandirian tersebut menjadi jauh lebih tinggi jika dibandingkan dengan kelas konvensional.
Dengan tingginya tingkat kemandirian dalam system belajar online maka penentu terbesar dari kesuksesan para siswa sudah pasti motivasi diri dalam belajar sebab Motivasi diri bisa menentukan seberapa besar usaha dan keinginan mengikuti pelajaran dan merupakan hal penting kesuksesan belajar (Allen, 2016).

\section{Belajar Online Dan Permasalahannya}

Mengacu pada faktor secara umum, maka kendala belajar online banyak melibatkan aspek-aspek dasar yang pada intinya adalah terkait pemerataan dan kesiapan, seperti perangkat pendukung misalnya media informasi, kemampuan guru hingga peserta belajarnya (Doucet, et all 2020). Meskipun kemudian unsur-unsur penerapannya berhasil terpenuhi baik dari aspek pendukung seperti teknologi maupun jaringan, tetap saja hal itu hanya akan lebih mudah untuk daerah-daerah perkotaan yang memang tingkat fasilitasnya memadai. Jika-pun kemudian berjalan, akan selalu ada celah menimbulkan kendala dalam proses pelaksanaannya karna fakta yang ada menunjukkan bahwa permasalahan belajar sistem online memang cukup kompleks dimana imbasnya bukan hanya terhadap Guru dan Siswa tapi juga orang tua.

Rigianti (2020) dalam penelitiannya terkait kendala pembelajaran daring guru sekolah dasar di kabupaten Banjarnegara misalnya, menemukan adanya kendala signifikan terkait kurang efektifnya pengelolaan pembelajaran seperti pemilihan materi dan penyampaiannya melalui kelas daring. Kendala serupa juga dihadapi oleh guru lainnya di Surakarta dalam penelitian yang dilakukan oleh Setyawan (2020) yang merasa bahwa klarifikasi atau penjelasan langsung terkait materi yang diberikan melalui kelas daring lebih sulit dibanding pertemuan offline. Tidak optimalnya penyampaian materi seperti yang disampaiakn oleh Suryaman dkk (2020) berakibat pada pembelajaran yang sia-sia untuk siswa. Lebih lanjut, Qadafi (2020) menemukan bahwa peralihan penyampaian materi bahasa inggris yang telah disiapkan guru untuk kelas luring lebih beresiko terhadap siswa belum mampu (pengetahuannya) saat disampaikan kedalam kelas virtual (daring) karena 
terbatasnya kedekatan pembimbingan langsung. Ini berarti bahwa, ada masalah signifikan yang dihadapi para guru selama kelas daring berlangsung.

Kajian pelaksanaan online learning selama ini, jika ditinjau dari segi syarat-syarat yang harus dimiliki pelajar/siswa, secara umum memposisikan peserta didik sebagai orang dewasa yang memiliki kemandirian tinggi sehingga mampu menjalankan sistem ini dengan baik, padahal, ketika COVID-19 mewabah, dampaknya telah dan sedang berimbas pada pendidikan di semua jenjang tak terkecuali pendidikan bagi anak-anak. Jika dilihat dari aspek kemandirian dan motifasi, On-line learning berpeluang tidak tepat bagi anak-anak terlebih jika ketersediaan pendampingan sangat minim sebab ada saja orang tua yang juga tetap harus bekerja selama kegiatan belajar berlangsung (Doucet, et all 2020).

Lebih jauh, dari fakta yang ditemukan, kendala selama online learning juga ternyata di alami oleh orang tua siswa yang terkadang tidak memiliki kemampuan untuk menjelaskan materi dengan detail (Anugrahana, 2020). Hal ini tentu saja didasari oleh lemahnya pemahaman materi oleh orang tua seperti yang dikemukakan oleh Wardani \& Ayriza (2020) dalam penelitiannya terkait Analisis Kendala Orang Tua dalam Mendampingi Anak Belajar di Rumah Pada Masa Pandemi Covid-19. Selain itu, para orang tua juga merasa terbebani karna harus menjalankan peran seorang guru untuk mengajar hingga selalu mengawasi anakanak mereka dan bahkan lebih berat lagi bagi orang tua yang tetap bekerja (Arwen, 2020).

Merangkum permasalahan diatas, penelitian ini akan terfokus pada factor hambatan pemahaman siswa selama belajar online dan tidak membahas ranah kendala sarana dan prasarana.

\section{METODE PENELITIAN}

Pendekatan kualitatif merupakan cara yang tepat jika fokus dari sebuah penelitian adalah untuk menghasilkan data deskriptif berupa ucapan, tulisan atau tingkah laku orangorang (Taylor, Bodgan \& DeVault, 2016).
Pendekatan kualitatif haruslah jujur terhadap respondent/subject penelitian dan orang lain yang menjadi pintu untuk bisa membantu mengakses informasi dari subject (key informant) namun tentu saja tidak harus detail karna subject/respondent tidak akan menjadi diri sendiri jika selama proses penelitian menyadari seberapa jauh dia akan diperhatikan (ibid). Jadi, 2 pihak yang akan dijelaskan terkait tujuan penelitian ini adalah "key informant" serta subject itu sendiri.

Metode observasi adalah pilihan pertama untuk mendukung pengumpulan data yang sesuai dengan tujuan penelitian ini. Namun, tentu saja untuk mengantisipasi adanya hal-hal penting yang tidak dapat diungkap selama proses pengamatan, maka penerapan Semi-structured Interview merupakan cara lain yang akan diaplikasikan dalam melengkapi informasi yang ingin digali terutama terkait alasan-alasan atau jawaban untuk pertanyaan "how" and "why". Populasi dari penelitian ini adalah seluruh siswa SMP yang ada di lingkungan Penan, pejarakan. Namun terkait pertimbangan efisiensi waktu dan ekonomis biaya serta unsur homogenitas dari populasi cukup tinggi, maka penelitian ini menggunakan sampel sebanyak 15 anak.

\section{HASIL DAN PEMBAHASAN}

Persiapan awal guna mendapatkan data dilakukan dengan mengumpulkan jadwal pelajaran bahasa Inggris para subject. Hal ini dimaksudkan agar peneliti lebih mudah melakukan pengamatan ketika proses belajar mereka berlangsung. Dari hasil penelitian melalui pengamatan, beberapa hal selama kegiatan belajar terpantau berjalan dengan variatif yakni baik dan kurang baik. Jika dilihat dari sudut subject, ada kecenderungan keterlambatan mengikuti kelas oleh siswa secara umum hampir 15-25 menit dan sedikit subject yang tepat waktu. Walaupun kegiatan belajar sudah dimulai namun subject terlihat masih saja belum memulai kegiatan belajar. Walaupun ada yang telah bersiap memegang HP namun terlihat juga masih mengerjakan hal lain seperti menonton TV, makan, menonton Tv atau menonton youtube. Hal ini sepertinya telah 
menjadi kebiasaan karna terlihat dilakukan beberapa kali dan sangat minim perubahan signifikan terkait ketidak disiplinan tersebut terutama dari siswa. Lebih lanjut, ditemukan juga kurang maksimalnya usaha factor eksternal yakni dari pendamping untuk tegas terhadap keterlambatan tersebut dari orang tua seperti peneguran dan hanya mengingatkan. Hal ini tentu lebih beresiko lagi ketika didapati fakta bahwa sebagian subject terkadang mengikuti kelas tanpa bimbingan keluarga sama sekali, (walaupun memang tidak semua subject) karna ada subject yang hanya mendapatkan keterlambatan pendampingan dan ada pula yang didampingi tidak sampai selesai. Fakta lainnya mengungkapkan bahwa, baik ketika belajar dengan pendampingan terlebih tanpa didampingi keluarga belajar beberapa kali sambil mengerjakan hal lain seperti membaca komik, makan, menonton Tv bahkan bermain game. Pun ketika siswa tidak berinisiatif untuk menciptakan hambatan selajar sendiri seperti mengerjakan hal lain, tingkat distraksi selama kegiatan belajar beberapa kali juga dijumpai karna terkadang siswa belajar sambil teralihkan fokusnya untuk menonton ketika mendengar sesuatu yang menarik baginya atau mendengarkan music dan bercanda dengan saudara termasuk juga terkadang hasrus melayani pembeli.

Dari segi pendampingan yang dilakukan oleh saudara (si subject) saat orang tua tidak bisa melakukan pendampingan, terkadang terlihat tidak berjalan mulus karna mereka berselisih paham (adu argument). Bahkan saudara pendamping agak menggerutu atau kesal kepada subject sewaktu-waktu selama proses belajar walaupun terkadang tidak menjadi perkelahian, walaupun tidak semua mengalami dan tidak bisa digeneralisasi namun factor ini kemudian penting menjadi salah satu catatan yang dapat dijadikan pertimbangan terkait dengan peran pendamping dan hal lain yang menarik adalah beberapa subject terlihat betah memegang HP di menit-menit awal dan kemudian mulai mengerjakan hal lain dipertengahan bahkan sampai akhir kelas.

Jika murni menngunakan 1 metode penelitian, makan banyak hal menarik dari pengamatan di atas yang tidak bisa dijelaskan alasan kenapa hal tersebut terjadi atau dilakukan. Sebut saja misalnya ketika belajar siswa sambil bermain game atau bahkan terlambat berkali-kali. Oleh karna itu, hal ini perlu kemudian digali lebih lanjut dengan melakukan wawancara. Wawancara ini dibagi kedalam 3 kendala utama yang ditemukan selama pengamatan yakni; terkait keterlambatan, mengerjakan hal lain dan tidak fokus, konsultasi pelajaran dengan orang tua serta akses menyelesaikan/mengerjakan tugas.

Jika dilihat dari tanggapan subject pada aspek keterlambatan, beberapa faktor penyebab yang ditemukan yakni dimulai dari terlambat bangun karna tidak pergi sekolah, ketika terlanjur mengerjakan hal lain seperti hal-hal yang disenangi, terkadang lupa dengan jadwal belajar. Selanjutnya ditemukan fakta dimana memang subject terbiasa mengikuti kelas terlambat padahal guru tepat waktu. Menurut sebagian subject, keterlambatan merupakan hal yang tidak akan menjadi penyebab untuk dimarah oleh guru karena gurunya baik. Subject juga menjelaskan bahwa guru tetap mengingatkan dan menegur tapi tidak pernah memarahi sehingga terbentuk persepsi bahwa selama mengikuti kelas, terlambat sedikit tidak apa-apa karna menurut penjelasan subject, teman-teman yang lainpun, walaupun tidak semua, ada yang terlambat absen dikelas daring.

Selanjutnya, alasan utama Terkait adanya kegiatan lain yang dilakukan selama kegiatan belajar lebih condong dikarenakan oleh tidak adanya kesempatan pengawasan (secara fisik) dan kurangnya tindakan langsung dari guru sehingga subject merasa bahwa tidak fokusnya (mengerjakan hal lain) dalam kegiatan belajar daring tidak akan diketahui oleh guru jadi tidak ada yang akan memarahi. Serupa dengan hal tersebut, orang tua-pun tidak marah ketika subject belajar sambil mengerjakan hal lain (makan, baca komik, nonton TV dll). Dari segi proses, didapati bahwa kegiatan belajar daring cenderung tidak banyak variasi, karna sebagian besar terdiri dari kegiatan menjelaskan dan mengerjakan tugas sehingga siswa bisa saja meninggalan kelas 
sebelum pelajaran selesai setelah guru menjelaskan. Dari segi pemahaman, subject menuturkan bahwa lebih sulit mengerti ketika membaca penjelasan materi, apalagi ketika penjelasan tersebut panjang dan tidak dipotong apalagi harus membaca materi saja untuk hal ini subject lebih memilih penjelasan langsung. Selain itu, interaksi dua arah yang terjadi antara Guru dan murid menjadi hambatan lain ketika proses belajar karena proses ini sangat menyita waktu sebab harus menunggu satu pihak selesai baru pihak yang lain dapat berkomentar. Hal lain yang menjadi alasan tidak fokusnya kegiatan belajar siswa adalah cenderung merasa bosan karna belajarnya harus sendiri, tidak bertemu guru dan teman-teman.

Kemudian, beberapa temuan pada bagian pendampingan dan konsultasi materi kepada orang tua yakni, selama berjalannya kegiatan belajar, terkadang dijumpai momen dimana orang tua tidak bisa mendampingi karna kegiatan lain atau pekerjaan rumah yang harus diselesaikan, praktis tidak bisa langsung berkonsultasi. Walaupun kemudian salah satu orang tua cukup paham terkait materi, sayangnya hanya bisa mendampingi saat pulang bekerja dan orang tua yang di rumah terlihat tidak bisa membantu banyak. Jadi, pertanyaan-pertanyaan saat kegiatan belajar tidak bisa dijawab langsung. Subject yang bertanya kepada orang tua tentang tugas-pun terkadang tidak mendapat jawaban langsung karna orang tua cenderung mengarahkan untuk bertanya ke keteman-teman dengan tingkat sekolah yang lebih tinggi atau bahkan keteman yang sudah selesai agar bisa mendapatkan jawaban. Hal ini tentu berkaitan dengan temuan lain dimana adanya kecendrungan untuk tidak bertanya kepada orang tua karna orang tua juga tidak mengerti pelajaran bahasa Inggris.

Lebih jauh, dari poin usaha siswa mengerjakan tugas, beberpa hambatan yang ditemui adalah ketika menanyakan ke orang tua. Beberapa subject memiliki salah satu orang tua yang mempunyai pemahaman yang cukup baik terkait pelajaran bahasa Inggris, namun sayangnya tidak bisa mendampingi kegiatan belajar karena bekerja. Jadi hanya bisa memberikan pendampingan penyelesaian tugas setelah pulang bekerja saja. Hal ini terkadang menyulitkan siswa dalam mengerjakan tugastugas langsung seperti pertanyaan-pertanyaan selama kegiatan belajar. Temuan lain masih serupa dengan temuan dibagian pendampingan yakni sebagian orang tua memang tidak tahu cara menjawab tugas yang diberikan sehingga beberapa orang tua yang tidak paham mengarahkan anak-anak mereka untuk belajar ke teman atau keluarga yang di tingkat SMA, namun kendalanya adalah adanya perasaan sungkan dari subject tidak mau bertanya ke kakak tingkat seperti siswa SMA yang ia kenal. Ketika ditanya terkait alasan perasaan sungkan tersebut, subject menjawab malu dan tidak mau karna rumahnya jauh serta malas dan memilih untuk menunda. Beberapa subject yang merasa kesulitan mengerjakan bahkan memilih tidak mengerjakan tugas dan menunggu teman lain untuk diikuti, dan jika lupa bahwa ada tugas yang harus dikerjakan, makan subject tidak dikerjakan dan tentu akhirnya tidak dikumpulkan.

Jika dilihat dari sudut orang tua terkait keterlambatan subject mengikuti kelas, usaha menegur dan mengingatkan subject sebenarnya sudah dilakukan, namun subject mengiyakan dan ada saja melakukan keterlambatan dan cukup sering. Bahkan ada orang tua yang mengatakan tidak terlalu mau terlalu menegur apalagi dengan keras karna subject pernah tidak mau belajar saat dimarahi dan lebih memilih pergi bermain. Bagi sebgaian besar orang tua yang memiliki hal untuk dikerjakan, baik dirumah maupun diluar rumah tentu saja tidak bisa terus-menerus melakukan pengawasan.

Hal lain yang juga menjadi temuan adalah terkait dengan adanya kegiatan belajar siswa tanpa pendampingan. Sebagian orang tua merasa bahwa tidak banyak hal yang bisa dijelaskan kepada anaknya karna memang tidak terlalu paham dan bahkan tidak tau bahasa Inggris. Jadi, orang tua subject terkadang mendampingi hanya memastikan anak-anak mengikuti kelas saja. Walaupun mereka mengerti sedikit, seperti sedikit tau kata-kata bahasa Inggris, mereka tetap memiliki kendala terkait proses menjelaskan kepada subject. Jadi ada kesimpulan dari beberapa orang tua bahwa 
dengan atau tanpa mereka, sebenarnya anakanak tidak bisa banyak terbantu terkait pemahaman materi. Selain itu, terkadang pekerjaan menjadi hambatan dalam mendampingi subject.

\section{PENUTUP}

\section{Kesimpulan}

Perlu penulis sampaikan terlebih dahulu bahwa penelitian ini tidak sepenuhnya berisikan kendala artinya selama kegiatan belajar ditemukan juga subject yang menjalani kegiatan dengan baik dan mendapat pendampingan yang baik, jadi hasil berupa permasalahan yang muncul tidak bisa digeneralisasikan untuk semua Subject. Hanya saja jika dilihat dari fokus penelitian ini adalah mencari tahu tentang hambatan atau kendala pemahaman subject terhadap kegiatan pembelajaran bahasa Inggris secara daring, maka merupakan suatu kewajaran jika dominasi serta tendensi "permasalahan" yang dimunculkan sebagai titik tekan atau fokus pembahasan. Permasalahan umum yang muncul dapat diklasifikasi menjadi 3 bagian yakni; 1) Adanya keterlambatan dari subject dalam mengikuti kegiatan kelas daring, seperti masih menonton Tv, Bermain game dan hal terkait lainnya saat kelas dimulai. 2) Adanya kecenderungan tidak serius mengikuti kegiatan belajar yang dengan fakta bahwa siswa selama belajar melakukan kegiatan lain seperti bermain game, menonton TV, mendengarkan music dan hal terkait seperti temuan diatas, serta 3) kurang maksimalnya waktu dan kemampuan pendamping selama proses belajar baik karna tidak memiliki pemahaman yang cukup terkait materi maupun adanya kegiatan lain atau pekerjaan yang harus dijalani.

\section{DAFTAR PUSTAKA}

[1] Allen, M.W (2016). Michael Allen's Guide to e-Learning, Second Edition. (Building Interactive, Fun and Effective Learning Programs for Any Company). Published by John Willey \& Sons, Inc., Hoboken, New Jersey.

[2] Anugrahana, Andi (2020). Hambatan, Solusi dan Harapan: Pembelajaran Daring
Selama Masa Pandemi Covid-19 Oleh Guru Sekolah Dasar. Scholaria: Jurnal Pendidikan dan Kebudayaan, Vol. 10 No. 3, September 2020: 282-289.

[3] Arwen, Desri (2020). Student Learning Motivation Influences The Development Of The Corona Virus Pandemic (COVID 19). International Journal of Advanced Science and Technology Vol. 29, No. 9s, (2020), pp. 4911-4925.

[4] Chitra, A.P \& Raj, M.A (2018). ELearning. Journal of Applied and Advanced Research, 2018: 3(Suppl. 1) S11-S13. Diakses pada 12 July 2020 dari https://dx.doi.org/10.21839/jaar.2018.v3S $\underline{1.158}$

[5] Dabbagh, Nada (2007). The Online Learner: Characteristics and Pedagogical Implications. Contemporary Issues in Technology and Teacher Education, 7(3), 217- 226.

[6] Doucet, Armand., et al (2020). Thinking about Pedagogy in an Unfolding Pandemic (An Independent Report on Approaches to Distance Learning During COVID19 School Closures), Version 2.0 | 29 March 2020.

[7] Hardianto, Deni (2012). Karateristik Pendidik dan Peserta Didik dalam Pembelajaran Online. Jurnal majalah ilmiah pembelajaran no 2 (2012).

[8] Hendrastomo, Grendi (2008). Dilema dan tantangan pembelajaran E-Learning. Majalah Ilmiah Pembelajaran, Volume 4. Nomor 1, Mei 2008.

[9] Litlejohn, Allison \& Pegler,Chris (2007). Preparing for Blended e-Learning. Published by Routledge, 2 Park Square.

[10]Munawaroh, Istiani (2005). Virtual Learning dalam pembelajaran jarak jauh. Majalah Ilmiah pembelajaran nomor 2, Vol.1, Oktober 2005.

[11]Qadafi, Muammar (2020). Pembelajaran Bahasa Inggris pada Anak di Sangkhom Islam Wittaya School saat Pandemi Covid19. Jurnal Obsesi : Jurnal Pendidikan Anak Usia Dini. Volume 5 Issue 1 (2021) Pages 422-430. DOI: 10.31004/obsesi.v5i1.591. 
[12]Rigianti, H.A. (2020). Kendala Pembelajaran Daring Guru Sekolah Dasar Di Kabupaten Banjarnegara. Elementary School 7 (2020) 297-302.

[13] Setiawardhani, S.T (2003). Pembelajaran Elektronik (E-Learning) Dan Internet Dalam Rangka Mengoptimalkan Kreativitas Belajar Siswa. Edunomic, Jurnal Ilmiah Pend. Ekonomi, Volume 1 Nomor 2, September 2013, Hal. 82-96.

[14] Setyawan, Cholis (2020). Challenges On Teaching Online English Subject In Smk Negeri 1 Nawangan. Diakses November 15-2020, 17.30 , dari http://eprints.ums.ac.id/84471/13/PU BLICATION\% 20ARTICLE.pdf .

[15] Surat Edaran No. 4, Tahun 2020 tentang Pelaksanaan Kebijakan Pendidikan dalam Masa Darurat Penyebaran Corona Virus Disease (Covid-19). Diakses pada 25 September (2020)

[16] Suryaman et.al (2020). Covid-19 pandemic and home online learning system: does it affect the quality of pharmacy school learning?. Systematic Reviews in Pharmacy Vol 11, Issue 8, Aug-Sep 2020.

[17] Taylor, S.T, Bodgan, Robert \& DeVault, M.L (2016).Introduction to Qualitative Research Methods (A Guide Book and Resource), Fourth Edition. Published by John Wiley \& Son, Inc., Hoboken, New Jersey.

[18] Wardani, Anita \& Ayriza, Yulia (2020). Analisis Kendala Orang Tua dalam Mendampingi Anak Belajar di Rumah Pada Masa Pandemi Covid-19. Jurnal Obsesi : Jurnal Pendidikan Anak Usia Dini, Volume 5 Issue 1 (2021) Pages 772-782. DOI: 10.31004/obsesi.v5i1.705.

[19] Yustanti, Ike \& Novita, Dian (2019). Pemanfaatan E-Learning Bagi Para Pendidik Di Era Digital 4.0. Prosiding Seminar Nasional Pendidikan Program Pascasarjana Universitas Pgri Palembang 12 Januari 2019. Diakses 5 oktober 2019 https://jurnal.univpgripalembang.ac.id/ind ex.php/Prosidingpps/article/view/2543. 